\title{
APLIKASI TEPUNG GEMBILI (Dioscorea esculenta) SEBAGAI SUBSTITUSI TEPUNG TERIGU PADA FILLER NUGGET IKAN TONGKOL (Euthynnus affinis)
}

\section{THE APPLICATION OF LESSER YAM FLOUR (Dioscorea esculenta) AS WHEAT FLOUR SUBTITUTION IN TUNA FISH (Euthynnus affinis) NUGGET FILLER}

\author{
Tyas Pratiwi ${ }^{1)}$, Dian Rachmawanti Affandi ${ }^{1)}$, Godras Jati Manuhara ${ }^{1)}$ \\ 1) Program Studi Ilmu dan Teknologi Pangan, Fakultas Pertanian, Universitas Sebelas Maret
}

\begin{abstract}
The aim of this research was to know the influence of lesser yamflour addition into tuna fish nugget toward chemical characteristics (water content, ash, protein, fat, and carbohydrate), physical characteristic (hardness), functional characteristic (fiber content and inulin) and censor characteristic of tuna fish nugget. The research used Complete Random Design (CRD) one factor with five variations. The variation was in the proportion of wheat flour and lesser yamflour as tuna fish nugget filler namely, F1 (20\%:0\%), F2 (15\%:5\%), F3 (10\%: 10\%), F4 (5\%:15\%), F5 (0\%:20\%). Each variation of treatments was repeated three time and each replication were analysed twice. The collected data were then analyzed by using one way ANOVA and was followed by DMRT test with $\alpha=5 \%$ if there was a signifant difference between treatments.

Based on the research, adding lesser yam flour as wheat flour substitution in tuna fish nugget filler had no influence in water content, fat, protein, and carbohydrate of tuna fish nugget, but it increased ash content, fiber, and inulin of tuna fish nugget. The addition of lesser yam flour into tuna fish nugget filler also decreased the hardness of the nugget. Moreover, the addition of lesser yam flour as wheat flour substitution in tuna fish nugget filler did not influence the panelists' preference level toward its censor characteristics (color, smell, taste, texture, and overall) of tuna fish nugget.
\end{abstract}

Keywords: lesser yam flour, wheat flour, tuna fish nugget

\section{ABSTRAK}

Tujuan dari penelitian ini adalah untuk mengetahui pengaruh penambahan tepung gembili pada nugget ikan tongkol terhadap karakteristik kimia (kadar air, abu, protein, lemak, karbohidrat), karakteristik fisik (hardness), karakteristik fungsional (kadar serat pangan dan inulin) dan karakteristik sensoris nugget ikan tongkol. Percobaan dilakukan dengan menggunakan Rancangan Acak Lengkap (RAL) 1 faktor dengan 5 variasi. Variasi perlakuan terletak pada proporsi jumlah tepung terigu dan tepung gembili sebagai filler nugget ikan tongkol yaitu F1(20\%: 0\%), F2 (15\%: 5\%), F3 (10\%: 10\%), F4 (5\%: 15\%) dan F5 (0\%: 20\%). Penelitian dilakukan dalam 3 kali ulangan perlakuan. Dalam setiap ulangan perlakuan dilakukan 2 kali analisa. Data yang diperoleh selanjutnya dianalisis dengan menggunakan One Way ANOVA dan jika terdapat beda nyata dilanjutkan dengan uji DMRT dengan $\alpha=5 \%$.

Berdasarkan penelitian, penambahan tepung gembili sebagai substitusi tepung terigu pada filler nugget ikan tongkol tidak berpengaruh terhadap kadar air, lemak, protein, dan karbohidrat nugget ikan tongkol, namun meningkatkan kadar abu, serat pangan, dan inulin nugget ikan tongkol. Penambahan tepung gembili pada filler nugget ikan tongkol juga menurunkan tingkat kekerasan (hardness) nugget ikan tongkol. Selain itu, penambahan tepung gembili sebagai substitusi tepung terigu pada filler nugget ikan tongkol juga tidak mempengaruhi tingkat kesukaan panelis terhadap karakteristik sensoris (warna, aroma, rasa, tekstur, dan overall) nugget ikan tongkol.

Kata kunci: Tepung gembili, tepung terigu, nugget ikan tongkol.

\section{PENDAHULUAN}

Berkembangnya isu penggunaan formalin sebagai pengawet pada ikan membuat masyarakat enggan untuk mengkonsumsi ikan, khususnya ikan air laut. Hal ini tentu saja berdampak pada semakin rendahnya konsumsi ikan masyarakat Indonesia. Data Statistik Kementerian Kelautan dan Perikanan pada tahun 2012 menunjukkan bahwa trend produksi perikanan Indonesia mengalami peningkatan sejak tahun 2003, dengan kenaikan rata-rata pada tahun 2003-2012 sebesar 11,29\%. 
Penyediaan ikan untuk konsumsi pada tahun 2012 sebesar $46 \mathrm{~kg} / \mathrm{kapita} / \mathrm{th}$, sedangkan jumlah konsumsi ikan nasional Indonesia hanya sebesar 33,89 kg/kapita/th.

Lebih tingginya jumlah penyediaan ikan dibandingkan dengan jumlah konsumsi ikan nasional Indonesia, mendorong adanya upaya diversifikasi produk hasil perikanan untuk penguatan ketahanan pangan dan peningkatan gizi melalui pemenuhan kebutuhan protein masyarakat Indonesia.

lkan tongkol merupakan salah satu ikan yang produksinya mengalami peningkatan. Berdasarkan statistik kelautan dan perikanan Indonesia, volume produksi ikan tongkol dan cakalang pada tahun 2011-2012 meningkat sebesar 9,35\%. Ikan tongkol memiliki kandungan protein sebesar 25\%, jumlah tersebut lebih tinggi daripada kandungan protein pada ikan tenggiri yang hanya sebesar 21,4\% (Suwamba, 2008 dalam Atmaja, 2009).

Selain itu, ikan tongkol juga memiliki kandungan asam lemak omega-3 yang cukup tinggi (Sanger, 2010) yaitu sebesar 1,5 g/100g (Khomsan, 2006 dalam Atmaja, 2009). Kandungan omega-3 bermanfaat untuk menetralkan kelebihan kolesterol di dalam tubuh manusia. Sehingga pemanfaatan ikan tongkol menjadi produk pangan potensial untuk dilakukan.

Pengolahan ikan merupakan salah satu cara untuk menyelamatkan hasil panen yang disertai dengan usaha peningkatan nilai tambah melalui rasa, aroma, kenampakan produk serta kandungan gizinya. Adanya usaha diversifikasi produk hasil perikanan diharapkan dapat meningkatkan pendayagunaan dan usaha pengolahan hasil perikanan, khususnya perikanan laut untuk diolah menjadi produk baru yang bergizi tinggi, enak, murah, dan mudah didapat. Salah satu bentuk olahan ikan yang dapat menjadi alternatif upaya diversifikasi produk olahan ikan adalah nugget ikan. Nugget merupakan produk olahan daging dan ikan yang digemari oleh masyarakat.

Nugget merupakan salah satu produk olahan daging dengan menggunakan teknologi restrukturisasi, yaitu teknologi dengan memanfaatkan potongan daging yang relatif kecil dan tidak beraturan, kemudian dilekatkan kembali menjadi ukuran yang lebih besar (Amertaningtyas et al., 2001). Nugget yang pada umumnya menggunakan daging ayam, dapat digantikan dengan menggunakan ikan. Pada dasarnya nugget ikan mirip dengan nugget ayam, perbedaannya hanya terletak pada bahan baku yang digunakan. Salah satu ikan yang dapat diolah menjadi nugget ikan adalah ikan tongkol.

Pada proses pembuatan nugget dibutuhkan adanya bahan pengisi (filler). Tujuan penambahan bahan-bahan lain, termasuk bahan pengisi adalah meningkatkan daya ikat air, meningkatkan flavor, mengurangi pengerutan selama pemasakan, meningkatkan karakteristik fisik dan kimiawi serta sensoris produk, dan mengurangi biaya formulasi (Rosyidi et al., 2008). Besarnya filler yang ditambahkan pada produk nugget umumnya sebesar 10\% (Astriani et al., 2013), hingga 30\% (Suseno et al., 2007). Bahan pengisi yang pada umumnya digunakan dalam pembuatan nugget adalah tepung terigu.

Di sisi lain, kebutuhan penduduk Indonesia terhadap tepung terigu belum dapat dipenuhi oleh pemerintah secara mandiri. Berdasarkan data dari Asosiasi Produsen Tepung Terigu Indonesia (APTINDO), pada tahun 2012 jumlah konsumsi tepung terigu nasional Indonesia adalah sebesar 5,068 juta ton/tahun, sedangkan jumlah impor gandum pada tahun 2011 sebesar 5,47 juta ton/tahun dan terus meningkat pada tahun 2012 sebesar 6,25 juta ton/tahun. Dengan tingginya jumlah impor tepung terigu, maka perlu adanya alternatif pengganti tepung terigu, misalnya pada filler nugget ikan tongkol.

Gembili (Dioscorea esculenta L.) merupakan umbi dari keluarga Dioscoreacea yang mempunyai keunggulan dapat tumbuh di bawah tegakan hutan. Namun, sampai saat ini gembili masih merupakan tanaman subsiten, yaitu bukan tanaman pokok yang dibudidayakan, karena pemanfaatannya masih terbatas (Prabowo et al., 2014). Berdasarkan data dari Kementrian Pertanian 
tahun 2013, produksi gembili di Indonesia sebesar 180 ton. Sejauh ini pengolahan umbi gembili hanya dilakukan dengan cara direbus, dikukus ataupun digoreng (Utami et al., 2013). Sebagai umbi dengan kandungan pati sebesar 21,44\% (Richana, dan Sunarti, 2010), umbi gembili sangat potensial untuk dikembangkan menjadi tepung umbi yang kemudian dapat diaplikasikan menjadi filler pada nugget. Sejauh ini, beberapa penelitian yang telah dilakukan mengenai tepung gembili yaitu penambahan tepung gembili pada proses pembuatan pangsit (Bekti, 2009), cookies (Prameswari, 2013), dan flakes (Gisca, 2013).

Keunggulan dari gembili adalah mengandung serat pangan dan senyawa bioaktif yaitu seperti inulin (Prabowo et al., 2014). Umbi gembili (Dioscorea esculenta) termasuk dalam umbi-umbian lokal yang memiliki kandungan serat tinggi yaitu sebesar 6,386\% (bk) (Yuniar, 2010). Menurut Richana dan Sunarti (2004), tepung gembili mengandung serat pangan tak larut air berupa selulosa, serta sedikit lignin dan hemiselulosa. Serat pangan tak larut air berperan dalam pencegahan disfungsi alat pencernaan seperti konstipasi, kanker usus besar, dan infeksi usus buntu (Muchtadi, 2001). Umbi gembili juga mengandung serat pangan larut air berupa Polisakarida Larut Air (PLA) dan inulin. Sifat PLA yang kental dan membentuk gel dapat menghambat penyerapan makronutrien dan menurunkan respon glukosa postprandial, sehingga memiliki efek hipoglikemik (Prabowo et al., 2014).

Inulin adalah salah satu karbohidrat yang berfungsi sebagai prebiotik yang efektif, didefinisikan sebagai komponen pangan yang tidak dapat dicerna dan dapat merangsang secara selektif pertumbuhan dan aktivitas bakteri yang menguntungkan di dalam saluran pencernaaan (Marsono, 2004). Gembili mengandung inulin sebesar $14,629 \%$ (bk). Inulin dapat mengurangi resiko kanker usus besar, menormalkan kadar gula darah dan membantu mempengaruhi penurunan kesehatan jantung dan mencegah kanker kolon (Azhar, 2009).
Dalam penelitian ini akan dikaji mengenai penggunaan tepung gembili sebagai substitusi tepung terigu pada filler nugget ikan tongkol. Diharapkan dengan penggunaan tepung gembili sebagai filler nugget ikan tongkol tersebut dapat memberikan alternatif produk pangan berbahan dasar ikan tongkol dengan karakteristik kimia, fisik, dan sensoris yang dapat diterima konsumen dengan memanfaatkan bahan lokal yang memberikan manfaat lebih bagi kesehatan.

\section{METODE PENELITIAN}

\section{A. Bahan}

Bahan-bahan yang digunakan dalam pembuatan tepung gembili antara lain umbi gembili ketan (diperoleh dari Pasar Harjodaksino, Surakarta), Na-metabisulfit, dan $\mathrm{NaCl}$. Bahan-bahan yang digunakan dalam pembuatan nugget ikan tongkol antara lain ikan tongkol (diperoleh dari Depo Ikan, Surakarta), tepung terigu, tepung gembili, susu skim, telur, tepung maizena, tepung roti, dan bumbu. Bahan-bahan yang digunakan untuk analisis nugget ikan tongkol antara lain petroleum benzene, larutan $\mathrm{HCl} 0,01 \mathrm{~N}$, $\mathrm{H}_{2} \mathrm{SO}_{4}, \mathrm{HgO}$, larutan $\mathrm{NaOH}-\mathrm{Na}_{2} \mathrm{~S}_{2} \mathrm{O}_{3}, \mathrm{~K}_{2} \mathrm{SO}_{4}$, $\mathrm{Na}_{2} \mathrm{~B}_{4} \mathrm{O}_{7} .10 \mathrm{H}_{2} \mathrm{O}, \quad \mathrm{H}_{3} \mathrm{BO}_{3}, \quad$ indikator (campuran 2 bagian metil merah 0,2\% dalam alkohol dan 1 bagian metilen blue $0,2 \%$ dalam alkohol), aquades, etanol 95\%, aquades, etanol $78 \%$, aseton, $\mathrm{Na}_{2} \mathrm{HPO}_{4}$ anhidrat, buffer fosfat $\mathrm{pH}$, Enzim Termanyl, $\mathrm{HCl} 4 \mathrm{~N}$, $\mathrm{NaOH} 4 \mathrm{~N}$, suspensi pepsin, suspensi pankreatin, larutan standar inulin, sistein $1,5 \%, \mathrm{H}_{2} \mathrm{SO}_{4} 70 \%$, dan karbazol $0,12 \%$ dalam larutan etanol.

\section{B. Alat}

Alat-alat yang digunakan dalam pembuatan tepung gembili antara lain pisau, alat pemotong, baskom, thermometer, cabinet dryer, blender, ayakan 80 mesh. Alat-alat yang digunakan dalam pembuatan nugget ikan tongkol antara lain alat penggiling daging, baskom, blender, alat pengukus, aluminium foil, freezer, kompor. Alat-alat 
yang digunakan untuk analisis nugget ikan tongkol antara lain cawan porselen, desikator "Iwaki", oven "Memmert", neraca analitik, tanur, alat ekstraksi sokhlet, kertas saring bebas lemak, pemanas kjeldahl, labu kjeldahl $30 \mathrm{ml} / 50 \mathrm{ml}$, alat distilasi lengkap dengan Erlenmeyer berpenampung berukuran $125 \mathrm{ml}$ dan buret $25 \mathrm{ml} / 50 \mathrm{ml}$, neraca analitik. waterbath, kertas saring whatman 40, kertas saring, spektrofotometer, universal testing machine "Zwick", piring kertas, dan nampan.

\section{Tahapan Penelitian}

\section{Pembuatan Tepung Gembili}

Umbi gembili yang digunakan pada pembuatan tepung pada penelitian ini adalah gembili ketan dengan ukuran $5-10 \mathrm{~cm}$ dan diameter 2,7-4 cm. Pembuatan tepung umbi gembili mengacu pada metode Utami, et al. (2013). Proses pembuatan tepung gembili diawali dengan perlakuan pendahuluan yaitu pencucian umbi dari tanah dan kotoran lainnya kemudian dilakukan proses blanching dengan cara direndam dalam air panas pada suhu $80{ }^{\circ} \mathrm{C}$ selama 1 menit hingga keseluruhan umbi terendam dalam air, kemudian dilakukan pengupasan kulit umbi gembili menggunakan pisau. Tahap selanjutnya yaitu pengirisan dengan slicer dengan ukuran ketebalan $1 \mathrm{~mm}-2 \mathrm{~mm}$ kemudian umbi direndam dalam larutan garam 5\% dan natrium metabisulfit $0,3 \%$ selama 2 jam. Selanjutnya dilakukan pencucian dengan air mengalir dan dilakukan pengeringan dengan cabinet dryer pada suhu $60{ }^{\circ} \mathrm{C}$ selama 6-8 jam. Kemudian umbi yang kering dilakukan penghancuran dengan blender dan diayak dengan ukuran 80 mesh.

\section{Pembuatan Nugget Ikan Tongkol}

Proses pembuatan nugget terdiri dari beberapa tahap mengacu pada penelitian yang dilakukan oleh Afrisanti (2010) dengan modifikasi. Tahap pertama yaitu penggilingan daging ikan tongkol menggunakan alat penggiling daging. Selanjutnya, daging ikan tongkol giling dicampur dengan bahan lain sesuai dengan masing-masing formula. Semua bahan diaduk manual menggunakan tangan selama $15-20$ menit sehingga menjadi adonan yang homogen. Adonan nugget tersebut dicetak dan dibungkus dengan menggunakan aluminium foil, kemudian dikukus selama 30 menit. Setelah proses pengukusan selesai, adonan nugget didinginkan pada suhu ruang $\left(25-27{ }^{\circ} \mathrm{C}\right)$, kemudian dimasukkan kedalam freezer selama 30 menit. Adonan yang telah padat ini disebut adonan setengah matang. Adonan kemudian dipotong-potong dengan ukuran kurang lebih $2 \times 2 \mathrm{~cm}$ dengan ketebalan satu $\mathrm{cm}$, selanjutnya adonan dilumuri dengan perekat tepung (batter) yang teridiri dari tepung terigu dan tepung maizena dengan perbandingan $1: 1$ dan air, kemudian dilumuri dengan tepung roti, kemudian dibekukan kembali dalam freezer. Nugget selanjutnya digoreng hingga matang.

\section{Pengujian Kualitas Nugget Ikan Tongkol}

Pengujian kualitas nugget ikan tongkol meliputi pengujian karakteristik kimia (kadar air, kadar abu, kadar lemak, kadar protein, kadar karbohidrat), karakteristik fisik (tekstur atau hardness), karakteristik fungsional (kadar serat pangan, inulin), dan analisis sensoris. Pada pengujian karakteristik kimia, fisik, dan fungsional, sampel nugget yang dianalisis merupakan sampel nugget mentah (sebelum proses penggorengan), sedangkan pada pengujian karakteristik sensoris sampel nugget yang digunakan yaitu nugget matang.

\section{E. Rancangan Penelitian}

Percobaan dilakukan dengan menggunakan Rancangan Acak Lengkap (RAL) 1 faktor dengan 5 variasi. Variasi perlakuan terletak pada proporsi jumlah tepung gembili yang disubstitusikan terhadap tepung terigu pada filler nugget ikan tongkol Penelitian dilakukan dalam 3 kali ulangan perlakuan. Dalam setiap ulangan perlakuan dilakukan 2 kali analisis. Data yang diperoleh selanjutnya dianalisis dengan menggunakan One Way ANOVA dan jika terdapat beda nyata dilanjutkan dengan uji DMRT dengan $\alpha=5 \%$ 


\section{HASIL DAN PEMBAHASAN}

\section{Kadar Air}

Air merupakan komponen penting dalam bahan makanan karena air dapat mempengaruhi penampakan, tekstur serta cita rasa dari makanan. Selain itu keberadaan air dalam bahan pangan juga menentukan daya awet dari suatu produk.

Tabel 1. Kadar Air Nugget Ikan Tongkol

\begin{tabular}{cc}
\hline Sampel & Kadar Air $(\% \mathbf{w b})$ \\
\hline F1 & $60,077^{\mathrm{a}} \pm 0,301$ \\
F2 & $60,612^{\mathrm{a}} \pm 0,537$ \\
F3 & $60,024^{\mathrm{a}} \pm 0,443$ \\
F4 & $60,018^{\mathrm{a}} \pm 0,702$ \\
F5 & $59,890^{\mathrm{a}} \pm 0,234$ \\
\hline
\end{tabular}

Keterangan : Angka yang diikuti huruf yang sama pada tiap kolom menunjukkan tidak beda nyata pada taraf $\alpha$ $=5 \%$. F1: $20 \%$ tepung terigu dan $0 \%$ tepung gembili; F2: $15 \%$ tepung terigu dan $5 \%$ tepung gembili; F3: $10 \%$ tepung terigu dan $10 \%$ tepung gembili; F4: $5 \%$ tepung terigu dan $15 \%$ tepung gembil

F5: $0 \%$ tepung terigu dan $20 \%$ tepung gembili

Berdasarkan Tabel 1, perbedaan proporsi tepung terigu dan tepung gembili pada filler pada nugget ikan tongkol tidak bepengaruh terhadap kadar air nugget ikan tongkol $(p>0,05)$. Kadar air nugget ikan tongkol berkisar antara 59,98\% hingga $60,61 \%$ (wb). Menurut SNI Nugget Ayam 016683-2002, kadar air maksmimal nugget ayam yaitu $60 \%(\mathrm{wb})$. Kadar air nugget ikan tongkol F1, F2, F3, dan F4 tidak memenuhi persyaratan SNI karena memiliki kadar air lebih besar dari 60\% (wb), sedangkan F5 memenuhi standar SNI karena memiliki kadar air sebesar 59,89\% (wb). Pada penelitian sebelumnya oleh Olivia (2013), subsitusi tepung terigu oleh tepung kulit udang dogol tidak mempengaruhi kadar air nugget jamur tiram.

Bahan penyusun merupakan faktor yang dapat mempengaruhi kadar air suatu produk pangan. Kadar air ikan tongkol sebagai bahan baku nugget ikan tongkol yaitu 72\% (Suwamba, 2008 dalam Atmaja, 2009). Bahan pengisi (filler) yang digunakan juga dapat mempengaruhi kadar air nugget, karena filler yang berupa tepung dapat meningkatkan kemampuan mengikat air (Afrisanti 2010).
Pada penelitian ini bahan yang digunakan sebagai filler yaitu tepung terigu dan tepung gembili. Berdasarkan penelitian yang dilakukan oleh Bekti (2009), tepung gembili memiliki kandungan air yang lebih rendah $(7,80 \%)$ dibandingkan dengan kandungan air pada tepung terigu yaitu sebesar $8,36 \%$. Tepung gembili yang digunakan pada pembuatan nugget ikan tongkol memiliki kadar air sebesar 7,09\%.

Perbedaan jumlah amilosa dan amilopektin pada filler nugget juga berpengaruh terhadap kadar air nugget yang dihasilkan. Tepung terigu memiliki kandungan amilosa dan amilopektin berturutturut adalah $28 \%$ dan $72 \%$, sedangkan tepung gembili memiliki kandungan amilosa sebesar 20,93\% dan amilopektin sebesar 79,07\% (Bekti, 2009). Menurut Maulida (2011), kadar amilosa yang lebih tinggi pada tepung terigu menyebabkan banyak air yang terperangkap karena sifat amilosa yang mudah menyerap air pada saat proses pembentukan gel selama pemanasan.

Kemampuan penyerapan air dan minyak pada tepung umbi dan tepung pati juga dipengaruhi oleh keberadaan serat kasar, karena sifat serat yang mudah menyerap air (Richana, dan Sunarti, 2004). Semakin tinggi kadar serat kasar dalam suatu bahan, maka kemampuan penyerapan air juga semakin tinggi. Kadar serat kasar pada tepung terigu sebesar 2,20\%, sedangkan kadar serat kasar tepung gembili yaitu sebesar 1,50\% (Ukpabi, 2010). Berdasarkan penelitian yang dilakukan oleh Richana, dan Sunarti (2004), tepung gembili memiliki kemampuan absorbsi air sebesar 1,91 g/g, sedangkan tepung terigu memiliki kemampuan absorbsi air yang lebih tinggi yaitu sebesar 2,00 g/g (Ukpabi, 2010).

\section{Kadar Abu}

Kadar abu adalah sisa yang tertinggal bila suatu sampel bahan pangan dibakar sempurna di dalam tungku pengabuan. Kadar abu menggambarkan banyaknya mineral yang tidak terbakar menjadi zat yang menguap (Apriyantono et al, 1989). Kadar abu nugget ikan tongkol ditunjukkan pada Tabel 2. 
Tabel 2. Kadar Abu Nugget Ikan Tongkol

\begin{tabular}{lcc}
\hline \multirow{2}{*}{ Sampel } & \multicolumn{2}{c}{ Kadar Abu } \\
\cline { 2 - 3 } & $\mathbf{\%}$ wb & $\mathbf{\%} \mathbf{d b}$ \\
\hline F1 & $1,94^{\mathrm{a}} \pm 0,15$ & $4,86^{\mathrm{a}} \pm 0,39$ \\
F2 & $2,10^{\mathrm{a}} \pm 0,09$ & $5,34^{\mathrm{b}} \pm 0,22$ \\
F3 & $2,33^{\mathrm{b}} \pm 0,04$ & $5,82^{\mathrm{c}} \pm 0,13$ \\
F4 & $2,47^{\mathrm{b}} \pm 0,10$ & $6,18^{\mathrm{c}} \pm 0,26$ \\
F5 & $2,59^{\mathrm{c}} \pm 0,09$ & $6,45^{\mathrm{d}} \pm 0,20$ \\
\hline
\end{tabular}

Keterangan : Angka yang diikuti huruf yang sama pada tiap kolom menunjukkan tidak beda nyata pada taraf $\alpha$ $=5 \%$. F1: $20 \%$ tepung terigu dan $0 \%$ tepung gembili; F2: $15 \%$ tepung terigu dan $5 \%$ tepung gembili; F3: $10 \%$ tepung terigu dan $10 \%$ tepung gembili; F4: $5 \%$ tepung terigu dan $15 \%$ tepung gembili; F5: 0\% tepung terigu dan $20 \%$ tepung gembili.

Berdasarkan Tabel 2, substitusi tepung gembili terhadap tepung terigu pada filler nugget ikan tongkol mempengaruhi kadar abu nugget ikan tongkol $(p<0,05)$. Kadar abu nugget ikan tongkol semakin meningkat seiring dengan meningkatnya jumlah tepung gembili yang disubstitusikan terhadap tepung terigu pada filler nugget ikan tongkol. Kadar abu nugget ikan tongkol berkisar antara 4,86\% - 6,45\% (wb). Menurut Bekti (2009), tepung gembili memiliki kadar abu sebesar 2,28\%, lebih tinggi dibandingkan dengan tepung terigu yaitu sebesar $1,9 \%$. Kadar abu yang tepung gembili yang digunakan pada proses pembuatan nugget ikan tongkol yaitu sebesar 4,26\%.

Ikan tongkol sebagai bahan baku utama pada proses pembuatan nugget memiliki kadar abu $0,7 \%$, serta kandungan vitamin dan mineral sebesar 1\% (Suwamba, 2008 dalam Atmaja, 2009). Menurut Suzuki (1981) dalam Andini (2006), tongkol juga mengandung unsur hara minor berupa mineral yang sangat penting bagi kehidupan manusia antara lain iodium dan fluor.

Kadar abu nugget yang tinggi menggambarkan kandungan mineral yang tinggi pula pada bahan pangan tersebut. Menurut Hanifa (2013), kandungan mineral yang tinggi pada nugget ayam dapat menyebabkan nugget menjadi masir, meskipun demikian tidak mempengaruhi tingkat kesukaan panelis terhadap nugget yang dihasilkan.

\section{Kadar Lemak}

Lemak dan minyak merupakan salah satu kelompok yang termasuk golongan lipida. Satu sifat yang khas dan mencirikan golongan lipida adalah daya larutnya dalam pelarut organik (misalnya: ether, benzene, khloroform) atau sebaliknya ketidaklarutannya dalam pelarut air (Sudarmadji et al., 1989).

Berdasarkan Tabel 3, penambahan tepung gembili sebagai filler nugget ikan tongkol tidak berpengaruh terhadap kadar lemak nugget ikan tongkol. Berdasarkan SNI Nugget Ayam 01-6683-2002, kadar lemak maksimal pada nugget ayam sebesar $20 \%$ (wb), sehingga kadar lemak nugget ikan tongkol pada kelima formula memenuhi persyaratan SNI. Pada pengujian kadar lemak nugget ikan tongkol, sampel yang digunakan merupakan nugget ikan tongkol mentah atau sebelum proses penggorengan sehingga tidak ada minyak yang terserap pada bahan. Menurut Bekti (2009) tepung terigu memiliki kadar lemak sebesar 1,3\% dan tepung gembili memiliki kadar lemak sebesar $0,45 \%$. Tepung gembili yang digunakan sebagai filler nugget ikan tongkol pada penelitian ini memiliki kadar lemak sebesar $0,83 \%$.

Tabel 3. Kadar Lemak Nugget Ikan Tongkol

\begin{tabular}{lcc}
\hline \multirow{2}{*}{ Sampel } & \multicolumn{2}{c}{ Kadar Lemak } \\
\cline { 2 - 3 } & $\mathbf{\%} \mathbf{w b}$ & $\mathbf{\%} \mathbf{d b}$ \\
\hline F1 & $1,19^{\mathrm{a}} \pm 0,19$ & $2,98^{\mathrm{a}} \pm 0,45$ \\
F2 & $1,28^{\mathrm{a}} \pm 0,20$ & $3,27^{\mathrm{a}} \pm 0,52$ \\
F3 & $1,10^{\mathrm{a}} \pm 0,18$ & $2,76^{\mathrm{a}} \pm 0,45$ \\
F4 & $1,31^{\mathrm{a}} \pm 0,15$ & $3,26^{\mathrm{a}} \pm 0,34$ \\
F5 & $1,63^{\mathrm{a}} \pm 0,30$ & $4,07^{\mathrm{a}} \pm 0,74$ \\
\hline
\end{tabular}

Keterangan : Angka yang diikuti huruf yang sama pada tiap kolom menunjukkan tidak beda nyata pada taraf $\alpha=5 \%$. F1: $20 \%$ tepung terigu dan $0 \%$ tepung gembili F2: $15 \%$ tepung terigu dan 5\% tepung gembili; F3: $10 \%$ tepung terigu dan $10 \%$ tepung gembili; F4: $5 \%$ tepung terigu dan $15 \%$ tepung gembili; F5: 0\% tepung terigu dan $20 \%$ tepung gembili.

. Pada penelitian nugget ikan tongkol ini kadar lemak tepung gembili yang digunakan untuk mensubstitusi tepung terigu memiliki kadar lemak yang lebih rendah $(0,83 \%)$ dibandingkan tepung terigu, meskipun demikian tidak berpengaruh terhadap kadar lemak nugget ikan tongkol $(\mathrm{p}>0,05)$. Komponen penyusun yang mempengaruhi 
kadar lemak nugget yaitu jenis daging yang digunakan. Ikan tongkol memiliki kadar lemak sebesar 1,30\% (Suwamba, 2008 dalam Atmaja, 2009). Kadar lemak nugget ikan tongkol yang dihasilkan yaitu berkisar antara $2,76 \%-4,07 \%(\mathrm{db})$. Menurut Khomsan (2006) dalam Atmaja (2009), ikan tongkol memiliki kandungan asam lemak omega 3 sebesar 1,5 g/100 g. Berdasarkan penelitian Sukarasa (2004) total omega 3 ikan tongkol yaitu sebesar $30,78 \%$. Perbedaan asam lemak omega 3 dari pada masing-masing jenis ikan disebabkan olah faktor makanan. Total omega 3 dihitung daori jumlah asam linoleat, EPA dan DHA. Kandungan DHA dan EPA pada ikan tongkol berturut-turut adalah 23,47\% dan $6,03 \%$. Perbedaan rasio DHA dan EPA pada berbagai jenis ikan dimungkinkan karena komposisi asam lemak tergantung pada spesies, habitat dan jenis makanan.

Mengkonsumsi asam lemak omega-3 dalam jumlah yang cukup mampu mengurangi kandungan kolesterol dalam darah dan mengurangi resiko terkena penyakit jantung, resiko artherosklerosis serta secara selektif dapat membunuh sel-sel kanker dan menyembuhkan simtom-simtom rheumathoid arthritis. Efek klinis dari asam lemak omega3 dalam menurunkan kadar kolesterol darah diduga disebabkan oleh pengaruhnya terhadap mekanisme produksi lipoprotein transport dalam hati yang disekresikan kedalam darah (Elisabeth, 1992 dalam Sukarasa, 2004)

\section{Kadar Protein}

Protein merupakan senyawa makronutrien bermolekul besar yang tersusun dari unsur-unsur $\mathrm{C}, \mathrm{H}, \mathrm{O}, \mathrm{N}, \mathrm{S}$, dan kadangkadang $\mathrm{P}, \mathrm{Fe}, \mathrm{Cu}$ sebagai senyawa kompleks dalam protein (Sudarmadji et al., 1989). Fungsi protein antara lain adalah sebagai pembangun struktur utama dalam sel, enzim dalam membran, hormon dan alat pembawa. Dilihat dari sisi nutrisi, protein merupakan sumber energi dan asam amino yang penting untuk pertumbuhan dan perbaikan sel (Susanto, 2012).

Berdasarkan Tabel 4, perbedaan proporsi tepung terigu dan tepung gembili sebagai filler nugget ikan tongkol tidak mempengaruhi kadar protein nugget ikan tongkol. Protein nugget ikan tongkol berkisar antara 27,54\% - 30,14\% (db). Berdasarkan SNI 01-6683-2002 tentang nugget ayam, kadar protein minimal nugget sebesar $12 \%$ (wb), sehingga kadar protein sample nugget ikan tongkol F5 tidak memenuhi persyaratan SNI, karena memiliki kadar protein sebesar $11,58 \%$ (wb).

Tabel 4. Kadar Protein Nugget Ikan Tongkol

\begin{tabular}{lcc}
\hline \multirow{2}{*}{ Sampel } & \multicolumn{2}{c}{ Kadar Protein } \\
\cline { 2 - 3 } & \% wb & \% db \\
\hline F1 & $12,17^{\mathrm{a}} \pm 0,37$ & $29,549^{\mathrm{a}} \pm 1,01$ \\
F2 & $12,58^{\mathrm{a}} \pm 0,32$ & $29,298^{\mathrm{a}} \pm 1,46$ \\
F3 & $12,66^{\mathrm{a}} \pm 0,47$ & $30,142^{\mathrm{a}} \pm 0,77$ \\
F4 & $12,34^{\mathrm{a}} \pm 0,96$ & $29,252^{\mathrm{a}} \pm 3,24$ \\
F5 & $11,58^{\mathrm{a}} \pm 0,53$ & $27,538^{\mathrm{a}} \pm 2,22$ \\
\hline
\end{tabular}

Keterangan : Angka yang diikuti huruf yang sama pada tiap kolom menunjukkan tidak beda nyata pada taraf $\alpha=5 \%$. F1: $20 \%$ tepung terigu dan $0 \%$ tepung gembili; F2: $15 \%$ tepung terigu dan 5\% tepung gembili; F3: $10 \%$ tepung terigu dan $10 \%$ tepung gembili; F4: $5 \%$ tepung terigu dan $15 \%$ tepung gembili; F5: $0 \%$ tepung terigu dan $20 \%$ tepung gembili

Rendahnya kadar protein sampel F5 diduga disebabkan oleh kadar protein tepung gembili yang lebih rendah daripada tepung terigu. Sampel F5 merupakan sampel nugget ikan tongkol dengan filler $20 \%$ tepung gembili. Berdasarkan penelitian yang dilakukan oleh Bekti (2009), tepung terigu memiliki kandungan protein sebesar 8,90\%, sedangkan tepung gembili memiliki kandungan protein sebesar 4,25\%. Pada penelitian ini tepung terigu yang digunakan yaitu tepung terigu protein tinggi dengan kadar protein $13 \%$, sedangkan tepung gembili yang digunakan memiliki kandungan protein sebesar $4,17 \%$.

Ikan tongkol sebagai bahan utama pembuatan nugget ikan tongkol memiliki kandungan protein sebesar 25\% (Suwamba, 2008 dalam Atmaja 2009). Protein juga digunakan sebagai bahan pengikat karena mempunyai bagian yang dapat berikatan dengan air (hidrofilik) dan bagian yang dapat mengikat lemak (lipofilik) (Abubakar et al., 2011). Bahan pengikat memiliki kontribusi yang besar terhadap daya emulsifikasi dan 
daya mengikat air pada adonan (Rossuartini, 2005). Pada penelitian ini bahan pengikat yang digunakan yaitu susu skim. Susu skim memiliki kandungan protein tinggi yaitu sebesar 37,4\% (Suryaningsih, 2015).

Suzuki (1981) dalam Rospiati (2006) menyatakan bahwa pembekuan dapat menyebabkan terjadinya denaturasi protein yang salah satunya adalah kelarutan protein sarkoplasma maupun miofibriler menurun. Protein sarkoplasma pada spesies ikan pelagik pada umumnya lebih besar dibadingkan dengan ikan demersal. Jumlah persentase mioglobinnya lebih besar dari hemoglobin dan sitokrom. Rospiati (2006) menyatakan bahwa denaturasi protein selama pembekuan diduga akibat adanya loss drip (cairan yang keluar/eksudasi) yang terjadi pada saat thawing. Drip menyebabkan beberapa nutrient seperti garam, polipeptida, asam amino, asam laktat, purin dan lain-lain yang larut dalam air akan terbawa bersama air yang keluar dari nugget. Polipeptida, asam amino dan asam laktat tersebut mengandung nitrogen yang hilang akibat drip dan tak terukur saat pengukuran dengan metode Kjeldhal dimana pengukurannya berdasarkan pengamatan jumlah nitrogen (Rospiati, 2006).

\section{Kadar Karbohidrat}

Pengukuran kadar karbohidrat dilakukan dengan metode by difference. Pada metode ini kadar karbohidrat diketahui bukan melalui analisis tetapi melalui perhitungan, sehingga bergantung kepada faktor pengurangnya, yaitu kadar air, kadar abu, kadar protein dan kadar lemak. Berdasarkan Tabel 5 penambahan tepung gembili tidak berpengaruh terhadap kadar karbohidrat nugget ikan tongkol $(p>0,05)$. Menurut SNI 01-6683-2002 tentang nugget ayam, syarat maksmimal kadar karbohidrat nugget $25 \%$ (wb). Sehingga nugget ikan tongkol pada seluruh variasi sampel memenuhi persyaratan SNI. Kadar karbohidrat nugget ikan tongkol berkisar antara 61,28 - 62,61\% (db). Kadar karbohidrat pada nugget di pengaruhi oleh jumlah bahan pengisinya. Semakin besar bahan pengisi maka semakin besar pula kandungan karbohidrat nugget. Hal tersebut dikarenakan bahan yang digunakan sebagai bahan pengisi pada umumnya merupakan tepung (Afrisanti, 2010).

Tabel 5. Kadar Karbohidrat Nugget Ikan

\begin{tabular}{lcc}
\hline \multirow{2}{*}{ Sampel } & \multicolumn{2}{c}{ Kadar Karbohidrat } \\
\cline { 2 - 3 } & $\mathbf{\%} \mathbf{w b}$ & $\mathbf{\%} \mathbf{d b}$ \\
\hline F1 & $24,62^{\mathrm{a}} \pm 0,61$ & $62,61^{\mathrm{a}} \pm 1,07$ \\
F2 & $23,42^{\mathrm{a}} \pm 0,55$ & $62,09^{\mathrm{a}} \pm 1,16$ \\
F3 & $23,89^{\mathrm{a}} \pm 0,46$ & $61,28^{\mathrm{a}} \pm 0,68$ \\
F4 & $23,86^{\mathrm{a}} \pm 1,32$ & $61,31^{\mathrm{a}} \pm 3,16$ \\
F5 & $24,63^{\mathrm{a}} \pm 0,50$ & $61,94^{\mathrm{a}} \pm 2,27$ \\
\hline
\end{tabular}

Keterangan : Angka yang diikuti huruf yang sama pada tiap kolom menunjukkan tidak beda nyata pada taraf $\alpha=5 \%$. F1: $20 \%$ tepung terigu dan $0 \%$ tepung gembili; F2: $15 \%$ tepung terigu dan $5 \%$ tepung gembili; F3: $10 \%$ tepung terigu dan $10 \%$ tepung gembili; F4: $5 \%$ tepung terigu dan $15 \%$ tepung gembili; F5: $0 \%$ tepung terigu dan $20 \%$ tepung gembili

Pada penelitian ini jumlah bahan pengisi yang ditambahkan sebesar $20 \%$ dari berat daging. Bahan pengisi yang digunakan merupakan tepung terigu dan tepung gembili. Pada penelitian nugget ikan tongkol ini tepung gembili yang digunakan untuk mensubstitusi tepung terigu memiliki kadar karbohidrat yang lebih tinggi $(83,17 \%)$ dibandingkan tepung terigu, meskipun demikian tidak berpengaruh terhadap kadar karbohidrat nugget ikan tongkol $(\mathrm{p}>0,05)$.

\section{A. Karakteristik Fisik Nugget Ikan Tongkol}

Tekstur merupakan unsur mutu yang penting pada produk olahan daging. Ciri yang sering menjadi acuan adalah kekerasan dan kandungan air (De Man, 1997 dalam Rospiati, 2006). Pengujian tekstur yang dilakukan pada nugget ikan tongkol ini yaitu hardness (kekerasan) nugget. Ranggana (1986) dalam Rospiati (2006) mendefinisikan kekerasan sebagai gaya yang dibutuhkan untuk menekan suatu produk sehingga menjadi produk yang diinginkan. Gaya tekan maksimal terhadap nugget menggambarkan tingkat kekerasan nugget tersebut. Penurunan gaya tekan mengindikasikan penurunan tingkat kekerasan suatu bahan pangan (Ansarifar et al., 2012).

Berdasarkan Tabel 6, penambahan tepung gembili berpengaruh terhadap gaya 
tekan maksimal nugget ikan tongkol, sehingga hal tersebut juga bepengaruh terhadap tingkat kekerasan nugget ikan tongkol $(\mathrm{p}>0,05)$. Semakin besar tingkat substitusi tepung gembili terhadap tepung terigu mengakibatkan semakin rendah gaya tekan maksimal nugget ikan tongkol, sehingga tingkat kekerasan nugget juga semakin menurun.

Tabel 6. Fmax Nugget Ikan Tongkol

\begin{tabular}{lc}
\hline Sampel & F max $(\mathbf{N})$ \\
\hline F1 & $17,45^{\mathrm{b}} \pm 0,61$ \\
F2 & $16,46^{\mathrm{b}} \pm 1,10$ \\
F3 & $12,65^{\mathrm{a}} \pm 1,14$ \\
F4 & $13,41^{\mathrm{a}} \pm 1,08$ \\
F5 & $13,27^{\mathrm{a}} \pm 1,14$ \\
\hline
\end{tabular}

Keterangan : Angka yang diikuti huruf yang sama pada tiap kolom menunjukkan tidak beda nyata pada taraf $\alpha$ $=5 \% . \mathrm{F} 1: 20 \%$ tepung terigu dan $0 \%$ tepung gembili; F2: $15 \%$ tepung terigu dan $5 \%$ tepung gembili; F3: $10 \%$ tepung terigu dan $10 \%$ tepung gembili; F4: $5 \%$ tepung terigu dan $15 \%$ tepung gembili; F5 : $0 \%$ tepung terigu dan $20 \%$ tepung gembili.

Peningkatan konsentrasi jumlah tepung sebagai filler nugget juga berarti semakin banyak jumlah pati yang akan mengisi ruangruang kosong dalam matriks gel sehingga tekstur nugget akan semakin padat dan cenderung keras (hardness tinggi) (Suseno, 2007).

Penurunan nilai kekerasan- pada nugget ikan tongkol diduga karena perbedaan kandungan pati pada bahan pengisi yang digunakan. Jumlah pati yang besar menyebabkan tekstur nugget menjadi lebih padat dan lebih cenderung keras (Potter 1973 dalam Rospiati 2006). Kandungan pati yang yang semakin tinggi menyebabkan gel yang terbentuk selama pemanasan juga semakin banyak dan meningkatkan kekerasan produk (Kusumanegara, et al., 2012). Tepung terigu memiliki kandungan pati sebesar $60-68 \%$ (Salim, 2010), sedangkan tepung gembili memiliki kandungan pati yang lebih rendah yaitu sebesar 21,44\% (Richana, dan Sunarti, 2010). Sehingga nugget ikan tongkol dengan filler tepung terigu memiliki tingkat kekerasan yang lebih tinggi daripada nugget ikan tongkol dengan filler tepung gembili.
Gembili merupakan salah satu umbi yang mengandung serat pangan. Kandungan serat pangan pada umbi gembili yaitu sebesar 6,386\% (Yuniar, 2010). Pada penelitian ini kandungan serat pangan nugget ikan tongkol meningkat seiring dengan semakin besarnya jumlah tepung gembili yang disubstitusikan terhadap tepung terigu pada filler nugget ikan tongkol. Hal tersebut berdampak pada menurunnya hardness nugget ikan tongkol. Firdevs (2004), dalam Melliyana et al. (2012) menyatakan bahwa partikel serat pangan lebih besar dari pada sel jaringan, sehingga menyebabkan matriks protein menjadi kurang homogen dan tidak kompak.

Keberadaan inulin sebagai salah satu serat pangan larut air juga mempengaruhi tingkat kekerasan (hardness) nugget ikan tongkol. Besarnya inulin yang pada nugget ikan tongkol sebanding dengan penambahan tepung gembili sebagai substitusi tepung terigu pada filler nugget ikan tongkol. Semakin tinggi kandungan inulin maka tingkat kekerasan nugget ikan tongkol semakin rendah. Hasil tersebut sesuai dengan penelitian yang dilakukan oleh Cegielka, dan Krzysztof (2012), penambahan inulin pada burger ayam menurunkan gaya tekan maksimal yang menggambarkan penurunan tingkat kekerasan burger ayam. Penurunan kekerasan dapat dikarenakan inulin tidak digunakan untuk mensubstitusi lemak.

\section{B. Karakteristik Fungsional Serat Pangan}

Definisi serat pangan yang disampaikan oleh The American Association of Cereal Chemist (AACC, 2001) adalah bagian yang dapat dimakan dari tanaman atau karbohidrat analog yang resisten terhadap pencernaan dan absorpsi pada usus halus dengan fermentasi lengkap atau parsial pada usus besar. Menurut Beck (2011), serat pangan ialah polisakarida bukan pati dari tumbuhan ditambah lignin. Serat pangan total (Total Dietary Fiber, TDF) terdiri dari dua komponen yaitu serat pangan larut (Soluble Dietary Fiber, SDF) dan serat pangan tidak larut (Insoluble Dietary Fiber, IDF). SDF diartikan sebagai serat pangan yang dapat larut dalam air hangat atau panas 
serta dapat terendapkan oleh air yang telah dicampur dengan empat bagian etanol. Gum, pektin, dan sebagian hemiselulosa larut yang terdapat dalam dinding sel tanaman merupakan sumber SDF. Sedangkan IDF diartikan sebagai serat pangan yang tidak larut dalam air panas atau dingin. Sumber IDF adalah selulosa, lignin, dan sebagian besar hemiselulosa (Muchtadi, 2001).

Berdasarkan Tabel 7, substitusi tepung gembili terhadap tepung terigu pada filler nugget ikan tongkol berpengaruh terhadap kadar serat pangan total nugget ikan tongkol $(p<0,05)$. Kadar serat pangan total nugget ikan tongkol berkisar antara 5,09\% hingga $18,46 \%$ (db). Kadar serat pangan pada nugget ikan tongkol semakin meningkat seiring dengan semakin banyaknya jumlah tepung gembili yang disubstitusikan terhadap tepung terigu pada filler nugget ikan tongkol. Hal tersebut dikarenakan umbi gembili memiliki kandungan serat pangan yang cukup tinggi yaitu sebesar 6,39\% (Yuniar, 2010). Menurut Portugal et al. (2013), tepung terigu memiliki kadar serat pangan yang lebih rendah yaitu $2,84 \%$.

Tabel 7. Serat Pangan Total Nugget Ikan

\begin{tabular}{lcc}
\hline \multirow{2}{*}{ Sampel } & \multicolumn{2}{c}{ Serat Pangan Total } \\
\cline { 2 - 3 } & \% wb & \% db \\
\hline F1 & $2,03^{\mathrm{a}} \pm 0,04$ & $5,087^{\mathrm{a}} \pm 0,06$ \\
F2 & $3,43^{\mathrm{b}} \pm 0,02$ & $8,686^{\mathrm{b}} \pm 0,05$ \\
F3 & $4,95^{\mathrm{c}} \pm 0,02$ & $12,348^{\mathrm{c}} \pm 0,08$ \\
F4 & $6,03^{\mathrm{d}} \pm 0,15$ & $15,202^{\mathrm{d}} \pm 0,23$ \\
F5 & $7,39^{\mathrm{e}} \pm 0,01$ & $18,461^{\mathrm{e}} \pm 0,06$ \\
\hline
\end{tabular}

Keterangan: Angka yang diikuti huruf yang sama pada tiap kolom menunjukkan tidak beda nyata pada taraf $\alpha$ $=5 \%$. F1: $20 \%$ tepung terigu dan $0 \%$ tepung gembili; $\mathrm{F} 2$ : $15 \%$ tepung terigu dan $5 \%$ tepung gembili; F3: $10 \%$ tepung terigu dan $10 \%$ tepung gembili; F4: $5 \%$ tepung terigu dan $15 \%$ tepung gembili; F5: 0\% tepung terigu dan $20 \%$ tepung gembili

Serat pangan tak larut terdiri dari tiga macam yaitu selulosa, hemiselulosa dan lignin. Tepung gembili mengandung selulosa serta sedikit lignin dan hemiselulosa, dengan jumlah 2,06\% (Richana, dan Sunarti, 2004). Serat pangan tidak larut (IDF) tidak terlalu signifikan sebagai agen hipokolestrolemik, tetapi perannya sangat penting dalam pencegahan disfungsi alat pencernaan seperti konstipasi (sulit buang air besar), haemoroid (ambeien), kanker usus besar, infeksi usus buntu, divertikulosisn dan colitis (Muchtadi, 2001).

Secara fisiologis serat pangan larut (SDF) lebih efektif dalam mereduksi plasma kolesterol yaitu Low Density Lipoprotein (LDL), serta meningkatkan kadar High Density Lipoprotein (HDL) (Muchtadi, 2001). LDL mengandung lebih banyak lemak daripada HDL sehingga LDL akan mengambang di dalam darah. LDL dianggap sebagai lemak yang "jahat" karena apabila jumlah LDL tersebut melebihi batas aman yang dapat ditoleransi oleh tubuh, ada kemungkinan kolesterol tertinggal di dinding pembuluh darah membentuk plak yang lamakelamaan dapat menyumbat pembuluh darah. Kadar LDL yang tinggi dan kadar HDL yang rendah dalam darah diduga dapat menyebabkan penumpukan kolesterol dalm dinding pembuluh darah yang mengakibatkan penyumbatan pembuluh darah yang disebut aterosklerotis atau ateroma. Apabila penyumbatan tersebut terjadi di pembuluh darah yang menuju ke jantung, maka akan memicu terjadinya penyakit jantung, sedangkan bila penyumbatan terjadi di pembuluh darah yang menuju ke otak, akan memicu terjadinya stroke. Sebaliknya HDL disebut sebagai lemak yang baik karena dalam operasinya dapat membersihkan kelebihan kolesterol dari dinding pembuluh darah dengan mengangkutnya kembali ke hati.

SDF juga bermanfaat bagi penderita diabetes mellitus yaitu berhubungan dengan peran SDF dalam mereduksi absorbsi glukosa dalam usus. Manfaat lain SDF adalah membuat perut merasa cepat kenyang, sehingga bermanfaat untuk mempertahankan berat badan normal (Muchtadi, 2001). Serat pangan larut (SDF) pada umbi gembili terdiri dari polisakarida larut air (PLA) dan inulin.

Serat pangan larut pada umbi gembili terdiri dari polisakarida larut air (PLA) dan inulin. Menurut Prabowo et al. (2014), umbi gembili mengandung polisakarida larut air (PLA), yaitu serat pangan larut air yang didefinisikan sebagai komponen dalam tanaman yang tidak 
terdegradasi secara enzimatis menjadi sub unit yang dapat diserap lambung dan usus halus. Jenis PLA yang utama pada kelompok Dioscorea yaitu glukomanan. Glukomanan merupakan polisakarida hidrokoloid yang mempunyai berat molekul antara 200.000 2.000.000 yang tersusun dari unit D-mannosa dan D-glukosa dengan rasio 1,6 : 1 diikat bersama-sama dalam ikatan $\beta-1,4$. Glukomanan mempunyai beberapa sifat fisik yang istimewa, antara lain pengembangan glukomanan di dalam air dapat mencapai 138 - 200\% dan terjadi secara cepat (pati mengembang $25 \%$ ).

\section{Kadar Inulin}

Inulin adalah polimer dari unit-unit fruktosa dengan gugus terminal glukosa. Unit-unit fruktosa dalam inulin dihubungkan oleh ikatan $\beta(2 \rightarrow 1)$ glikosidik. Inulin dari tanaman biasanya mengandung 20 sampai beberapa ribu unit fruktosa(Roberfroid, 2005 dalam Zubaidah dan Akhdiana, 2013).

Tabel 8. Kadar Inulin Nugget Ikan Tongkol

\begin{tabular}{lcc}
\hline \multirow{2}{*}{ Sampel } & \multicolumn{2}{c}{ Kadar Inulin } \\
\cline { 2 - 3 } & \% wb & \% db \\
\hline F1 & $0,0565^{\mathrm{a}} \pm 0,00005$ & $0,1372^{\mathrm{a}} \pm 0,00045$ \\
F2 & $0,0608^{\mathrm{b}} \pm 0,00160$ & $0,1414^{\mathrm{b}} \pm 0,00020$ \\
F3 & $0,0606^{\mathrm{b}} \pm 0,00160$ & $0,1460^{\mathrm{c}} \pm 0,00030$ \\
F4 & $0,0634^{\mathrm{b}} \pm 0,00210$ & $0,1498^{\mathrm{d}} \pm 0,00000$ \\
F5 & $0,0660^{\mathrm{c}} \pm 0,00235$ & $0,1565^{\mathrm{e}} \pm 0,00003$ \\
\hline
\end{tabular}

Keterangan : Angka yang diikuti huruf yang sama pada tiap kolom menunjukkan tidak beda nyata pada taraf $\alpha$ $=5 \%$. F1: $20 \%$ tepung terigu dan $0 \%$ tepung gembili; F2: $15 \%$ tepung terigu dan $5 \%$ tepung gembili; F3: $10 \%$ tepung terigu dan $10 \%$ tepung gembili; F4: $5 \%$ tepung terigu dan $15 \%$ tepung gembili; F5: 0\% tepung terigu dan $20 \%$ tepung gembili

Berdasarkan Tabel 8, penambahan tepung gembili sebagai filler nugget berpengaruh terhadap kadar inulin nugget ikan tongkol. Kadar inulin nugget ikan tongkol berkisar antara $0,14 \%$ hingga $0,16 \%$ (db). Kadar inulin nugget ikan tongkol semakin meningkat seiring dengan semakin besar jumlah tepung gembili yang disubstitusikan terhadap tepung terigu pada filler nugget ikan tongkol. Hal tersebut dikarenakan umbi gembili memiliki kadar inulin yang cukup tinggi yaitu 14,63\%
(Yuniar, 2010), sedangkan gandum sebagai bahan baku terigu mengandung sedikit inulin yaitu sebesar $1-3,8 \%$ (Nair et al., 2010). Dengan tingginya kadar inulin pada umbi gembili maka diduga tepung gembili juga mengandung inulin yang cukup tinggi.

Pada formulasi nugget ikan tongkol, juga ditambahkan bawang merah dan bawang putih. Bawang merah dan bawang putih yang ditambahkan yaitu sebesar $0,5 \%$ dan $1 \%$ dari berat daging. Bawang merah dan bawang putih selain berkonstribusi terhadap rasa nugget ikan tongkol juga merupakan bahan yang dapat meningkatkan kadar inulin nugget ikan tongkol. Umbi bawang merah mengandung inulin sebesar $2-6 \%$ (Franck, 2002), dan bawang putih mengandung inulin sebesar $9-16 \%$ (Nair et al., 2010).

Inulin sangat luas penggunaannya dalam industri pangan. Franck (2002), dalam Nair et al., (2010) menyatakan bahwa inulin mungkin dapat memperbaiki karakteristrik organoleptik. Penggunaan inulin dapat digunakan sebagai pengganti gula dan lemak yang menghasilkan kalori lebih rendah (Winarti et al., 2011). Inulin dapat memperbaiki karakteristik organoleptik secara signifikan, diantaranya meningkatkan rasa dan mouthfeel (Franck, 2002). Inulin juga dapat meningkatkan stabilitas emulsi, sehingga dapat digunakan untuk menggantikan stabilizer pada makanan, seperti pada es krim, dan saus (Nair et al., 2010). Inulin dapat digunakan sebagai bahan penstabil dikarenakan inulin tidak berasa, terdispersi baik dalam air dan cocok dikombinasikan dengan bahan pangan rendah lemak seperti susu skim (Azhar, 2009).

Ketika inulin dicampur dengan air atau bahan cair lainnya maka akan membentuk partikel gel berwarna putih krem yang mudah menyatu dalam bahan pangan sehingga dapat berfungsi sebagai pengganti lemak (Nair et al, 2010). Penggunaan inulin sebagai pengganti lemak pada sosis ayam meningkatan hardness dari sosis ayam (Menegas, 2013). Hal tersebut diduga inulin belum mampu menggantikan lemak sepenuhnya, sehingga meningkatkan hardness produk yang dihasilkan, namun penambahan inulin (tanpa mengurangi lemak) 
dapat menurunkan hardness produk akhir, seperti pada penelitian Cegielka, dan Krzysztof, (2012) pada burger ayam. Penambahan inulin pada burger ayam dapat menurunkan gaya tekan maksimal yang menggambarkan penurunan tingkat kekerasan burger ayam. Mendoza et al. (2001), mengemukakan bahwa penambahan inulin tidak mempengaruhi tingkat kekerasan sosis mentah namun dapat menurunkan kekenyalan (springiness) produk akhir. Menegas (2001), mengemukakan bahwa pengaruh inulin terhadap kekerasan tergantung dari bentuk inulin yang digunakan. Penambahan inulin dalam bentuk gel menghasilkan produk dengan tekstur yang lebih lembut daripada produk yang diberi penambahan inulin bubuk.

Inulin adalah makanan yang baik bagi Bifidobacteria' dan Lactobacilli karena mudah dan cepat difermentasi oleh bakteri tersebut. Kedua bakteri tersebut mampu menghambat pertumbuhan bakteri patogen. Produk fermentasi dari Bifidobacteria dan Lactobacilli menghasilkan Short Chain Fatty Acid (SCFA) dan L-laktat yang dapat menurunkan $\mathrm{pH}$ kolon sehingga dapat menaikkan pertumbuhan Lactobacilli dan Bifidobacteria, serta menurunkan aktivitas enzim bakterial yang terlibat pada sintesis produk yang bersifat karsinogen dan toksik dalam usus. Pembentukan SCFA dan L-laktat SCFA juga mempengaruhi imun, kesehatan jantung, dan mencegah kanker kolon. Senyawa yang termasuk SCFA adalah asetat, propionat, dan butirat (Azhar, 2009).

\section{Karakteristik Sensoris}

Hasil analisis sensoris nugget ikan tongkol dapat dilihat pada Tabel 9. Substitusi tepung gembili terhadap tepung terigu pada filler nugget ikan tongkol tidak berpengaruh terhadap tingkat kesukaan panelis pada warna nugget ikan tongkol $(\mathrm{p}>0,05)$. Tingkat kesukaan panelis terhadap paramater warna nugget ikan tongkol berkisar antara netral hingga suka.

Menurut Alsuhendra dan Ridawati (2007) salah satu kelemahan tepung gembili yaitu warna tepung yang agak gelap karena terjadinya reaksi pencoklatan selama proses pengolahan, namun nugget ikan tongkol dengan filler tepung gembili secara kasat mata memiliki warna yang tidak berbeda dengan nugget ikan tongkol dengan filler tepung terigu. Tingkat kesukaan terhadap warna nugget ikan tongkol tidak dipengaruhi oleh penambahan tepung gembili.

Tabel 9. Tingkat Kesukaan Nugget Ikan

\begin{tabular}{llllll}
\hline \multirow{2}{*}{ Sampel } & \multicolumn{5}{c}{ Karakteristik Sensoris } \\
\cline { 2 - 6 } & Warna & Aroma & Rasa & Tekstur & Overall \\
\hline F1 & $3,68^{\mathrm{a}}$ & $3,48^{\mathrm{a}}$ & $3,76^{\mathrm{a}}$ & $3,84^{\mathrm{a}}$ & $3,72^{\mathrm{a}}$ \\
F2 & $3,56^{\mathrm{a}}$ & $3,60^{\mathrm{a}}$ & $3,56^{\mathrm{a}}$ & $3,68^{\mathrm{a}}$ & $3,64^{\mathrm{a}}$ \\
F3 & $3,28^{\mathrm{a}}$ & $3,60^{\mathrm{a}}$ & $3,96^{\mathrm{a}}$ & $3,88^{\mathrm{a}}$ & $3,96^{\mathrm{a}}$ \\
F4 & $3,24^{\mathrm{a}}$ & $3,48^{\mathrm{a}}$ & $3,80^{\mathrm{a}}$ & $3,92^{\mathrm{a}}$ & $3,80^{\mathrm{a}}$ \\
F5 & $3,12^{\mathrm{a}}$ & $3,52^{\mathrm{a}}$ & $3,36^{\mathrm{a}}$ & $3,52^{\mathrm{a}}$ & $3,40^{\mathrm{a}}$ \\
\hline
\end{tabular}

Keterangan : Angka yang diikuti huruf yang sama pada tiap baris menunjukkan tidak beda nyata pada taraf $\alpha=5 \%$. Skor nilai : 1) sangat tidak suka, 2) tidak suka, 3) netral, 4) suka, 5) sangat suka. F1: 20\% tepung terigu dan $0 \%$ tepung gembili; F2: $15 \%$ tepung terigu dan $5 \%$ tepung gembili; $\mathrm{F} 3: 10 \%$ tepung terigu dan $10 \%$ tepung gembili; F4: $5 \%$ tepung terigu dan $15 \%$ tepung gembili; F5: $0 \%$ tepung terigu dan 20\% tepung gembili

Warna nugget ikan tongkol adalah kecoklatan. Hal tersebut dikarenakan ikan tongkol merupakan jenis ikan yang memiliki daging merah. Daging merah ikan adalah lapisan daging ikan yang berpigmen kemerahan sepanjang tubuh ikan di bawah kulit tubuh. Daging merah mengandung mioglobin dan hemoglobin yang bersifat prooksidan serta kaya dengan lemak (Okada, 1990 dalam Rospiati, 2006).

Aroma merupakan salah satu faktor pendukung cita rasa yang menentukan kualitas suatu produk. Aroma juga merupakan salah satu indikator untuk menentukan tingkat penerimaan suatu produk oleh konsumen. Menurut De man (1989) dalam Atmaja (2009), pengujian aroma dalam suatu produk baru dianggap penting karena cepat memberikan hasil penilaian terhadap produk terkait diterima atau tidaknya suatu produk. Timbulnya aroma atau bau ini karena zat bau tersebut bersifat volatil (mudah menguap).

Berdasarkan Tabel 9, substitusi tepung gembili terhadap tepung terigu pada filler nugget ikan tongkol tidak mempengaruhi 
tingkat kesukaan panelis terhadap parameter aroma nugget ikan tongkol $(p>0,05)$. Tingkat kesukaan panelis aroma nugget ikan tongkol berkisar antara netral hingga suka. Menurut SNI 01-6683-2002 mengenai nugget ayam, nugget harus memiliki aroma yang normal sesuai dengan bahan yang digunakan. Nugget ikan tongkol memiliki aroma khas ikan yang agak amis.

Berdasarkan Tabel 9, penambahan tepung gembili tidak mempengaruhi tingkat kesukaan panelis terhadap parameter rasa nugget ikan tongkol $(p>0,05)$. Tingkat kesukaan panelis terhadap rasa nugget ikan tongkol berkisar antara netral hingga suka. Menurut SNI 01-6683-2002 mengenai nugget ayam, nugget harus memiliki rasa yang normal sesuai dengan bahan yang digunakan. Nugget ikan tongkol memiliki rasa khas ikan tongkol.

Rasa nugget ikan tidak hanya dipengaruhi oleh jumlah daging ikan ataupun tepung yang digunakan, namun kemungkinan juga dipengaruhi rasa dari bumbu-bumbu yang ditambahkan (Surawan, 2007). Garam ditambahkan pada proses pembuatan nugget dengan tujuan menambah cita rasa, penambahan garam ini berkisar antara 1\% hingga $8 \%$ tergantung kesukaan. Gula juga ditambahkan pada proses pembuatan nugget dengan tujuan untuk meningkatkan cita rasa produk akhir yang lebih kenyal. Pada penelitian nugget ikan tongkol ini, garam yang ditambahkan sebesar 1,8\% dari berat daging ikan tongkol, sedangkan gula yang ditambahkan hanya sebesar $1 \%$. Rempahrempah merupakan komponen aromatik nabati yang sebagian besar dimanfaatkan sebagai bumbu untuk meningkatkan cita rasa dari produk yang dihasilkan. Beberapa rempah-rempah yang ditambahkan selama proses pembuatan nugget adalah lada, dan bawang putih (Price dan Schweigrt, 1987 dalam Rossuartini, 2005).

Berdasarkan Tabel 9, penambahan tepung gembili sebagai filler nugget ikan tongkol tidak mempengaruhi tingkat kesukaan panelis pada parameter tekstur ( $p>0,05)$. Tingkat kesukaan panelis pada parameter tekstur yaitu antara netral hingga suka. Menurut SNI 01-6683-2002 mengenai nugget ayam, nugget harus memiliki tekstur yang normal.

Perubahan yang terjadi selama proses penggorengan yaitu penguapan air. Peningkatan suhu selama proses penggorengan menyebabkan keluarnya air dari bahan pangan sehingga produk menjadi renyah. Pinthuss et al. (1995) menambahkan bahwa jumlah air bahan setelah penggorengan akan menentukan hardness suatu bahan pangan. Menurut Potter (1973), dalam Rospiati (2006), tekstur akan berubah dengan berubahnya kandungan air. Selain kandungan airnya, tekstur juga dipengaruhi oleh kandungan jumlah filler yang digunakan. Semakin besar jumlah filler yang ditambahkan menyebabkan tekstur menjadi lebih padat dan lebih cenderung keras (Potter 1973, dalam Rospiati 2006). Semakin tinggi konsentrasi tepung yang ditambahkan sebagai filler nugget maka akan semakin banyak pula jumlah pati yang akan mengisi ruang-ruang kosong dalam matriks gel sehingga tekstur nugget akan semakin padat dan cenderung keras (Suseno, 2007).

Kesukaan dan penerimaan konsumen terhadap suatu bahan mungkin tidak hanya dipengaruhi oleh satu faktor, akan tetapi dipengaruhi oleh berbagai macam faktor sehingga menimbulkan penerimaan yang utuh. Tujuan dari pengujian kesukaan overall yaitu untuk mengetahui tingkat kesukaan dari keseluruhan atribut mutu yang ada (Atmaja, 2009). Kesukaan dipengaruhi oleh berbagai macam faktor antara lain aroma, rasa, tekstur dan kekerasan, berbagai macam faktor tersebut menimbulkan penerimaan yang utuh (Puspitasari, 2008).

Penambahan tepung gembili sebagai filler nugget ikan tongkol tidak berpengaruh terhadap tingkat kesukaan panelis pada parameter warna, aroma, rasa, dan tekstur nugget ikan tongkol, sehingga hal tersebut juga tidak mempengaruhi tingkat kesukaan panelis terhadap overall nugget ikan tongkol pada level pengujian yang sama $(\alpha=5 \%)$. Tingkat kesukaan panelis terhadap nugget ikan tongkol dengan filler tepung gembili tidak berbeda nyata dengan nugget ikan 
tongkol yang menggunakan tepung terigu sebagai bahan pengisinya, sehingga penggunaan tepung gembili sebagai filler nugget memiliki prospek yang baik untuk dikembangkan berdasarkan hasil analisis pada beberapa parameter sensoris.

\section{KESIMPULAN}

Penambahan tepung gembili sebagai substitusi tepung terigu pada filler nugget ikan tongkol tidak berpengaruh terhadap kadar air, lemak, protein, dan karbohidrat nugget ikan tongkol, namun meningkatkan kadar abu, serat pangan, dan inulin nugget ikan tongkol. Penambahan tepung gembili sebagai substitusi tepung terigu pada filler nugget ikan tongkol juga menurunkan tingkat kekerasan (hardness) nugget ikan tongkol.

Penambahan tepung gembili sebagai substitusi tepung terigu pada filler nugget ikan tongkol tidak berpengaruh terhadap tingkat kesukaan panelis terhadap karakteristik sensoris (warna, aroma, rasa, tekstur, dan overall) nugget ikan tongkol.

\section{DAFTAR PUSTAKA}

AACC. 2001. The Definition of Dietary Fiber. World : Cereal Fds.

Abubakar, T. Suryati dan A.Azizs. 2011. Pengaruh Penambahan Karagenan Terhadap Sifat Fisik, Kimia, dan Palatabilitas Nugget Daging Itik Lokal (Anas platyrynchos). Seminar Nasional Teknologi Peternakan dan Veteriner.

Afrisanti, D. W. 2010. Kualitas Kimia dan Organoleptik Nugget Daging Kelinci dengan Penambahan Tepung Tempe. Skripsi Program Studi Peternakan, Fakultas Pertanian, Universitas Sebelas Maret Surakarta.

Almatsier, S. 2002. Prinsip-Prinsip Dasar Ilmu Gizi. Jakarta : Gramedia Pustaka Utama.

Andini, Y.S. 2006. Karakteristik Surimi Hasil Ozonisasi Daging Merah Ikan
Tongkol (Euthynnus sp.). Skripsi Program Studi Teknologi Hasil Perikanan, Fakultas Perikanan dan Ilmu Kelautan, Institut Pertanian Bogor.

Ansarifar, E., Mohebbat Mohebbi, dan Fakhri Shahidi. 2012. Studying Some Physicochemical Characteristics of Crust Coated with White Egg and Chitosan Using a Deep-Fried Model System. Food And Nutrition Sciences, Vol. 3, Hal. 685-692.

Apriyantono, A., D. Fardiaz, N.L. Puspitasari, Sedarnawati dan S. Budiyanto. 1989. Analisis Pangan. Bogor: IPB Press. Astriani, R.P., Kusrahayu, dan S. Mulyani. 2013. Pengaruh Berbagai Filler (Bahan Pengisi) Terhadap Sifat Organoleptik Beef Nugget. Animal Agriculture, Vol. 2, No. 1, Hal. 247252.

Atmaja, A.K. 2009. Aplikasi Asap Cair Redestilasi pada Karakterisasi Kamaboko Ikan Tongkol (Euthynus Affinis) Ditinjau dari Tingkat Keawetan dan Kesukaan Konsumen. Skripsi Program Studi Teknologi Hasil Pertanian, Fakultas Pertanian, Universitas Sebelas Maret Surakarta.

Azhar, M. 2009. Inulin Sebagai Prebiotik. Jurnal Sainstek, Vol. 12, No. 1.

Beck, M. E. 2011. Ilmu Gizi dan Diet, Hubungannya dengan PenyakitPenyakit untuk Perawat \& Dokter. Yogyakarta : Penerbit Andi.

Bekti, E. 2009. Karakteristik Kimiawi dan

Tingkat Pengembangan Pangsit dengan Substitusi Tepung Gembili (Dioscorea aculeata). Jurnal Teknologi Pangan dan Hasil Pertanian, Vol. 5, No. 2, Hal 99-111. Cegielka, Aneta, dan Krzysztof Tambor. 2012. Effect of Inulin on the Physical, Chemical, and Sensory Quality Attributes of Polish Chicken Burgers. Journal of Food Research, Vol. 1, No. 1.

De Man, J. M. 1989. Kimia Makanan. Bandung : ITB Press. 
Dewanti, F.K. 2013. Substitusi Inulin Umbi Gembili (Dioscorea esculenta) pada Produk Es Krim sebagai Alternatif Produk Makanan Tinggi Serat dan Rendah Lemak. Skripsi Program Studi Ilmu Gizi, Fakultas Kedokteran, Universitas Diponegoro Semarang.

Eastwood, M.A. 1992. The Physicological Effect of Dietary Fibre : An Update. An Rev. of Nutr., Vol. 12, Hal. 1935.

Evanuarini, Herly. 2010. Kualitas Chicken Nugget dengan Penambahan Putih Telur. Jurnal Ilmu dan Teknologi Hasil Ternak, Vol. 5, No. 2, Hal. 1722.

Firdevs, S. 2004. Effect of Different Batter Formulations on Quality of DeepFat Friend Chicken Nugget. A Review, Thesis, Food Science.

Franck, A. 2002. Technological Functionality of Inulin and Oligofructose. Journal Nutrition Britania, Vol. 87, Hal. 287291.

Gisca, Bernadetha. 2013. Penambahan Gembili pada Flakes Jewawut Ikan gabus Sebagai Alternatif Makanan Tambahan Anak Gizi Kurang. Skripsi program Studi Ilmu Gizi, Fakultas Kedokteran, Universitas Diponegoro Semarang.

Hadiwiyoto. 1993. Teknologi Pengolahan Hasil Perikanan. Yogyakarta : Liberty.

Hakim, U.N., Djalal Rosyidi, dan Aris Sri W. 2013. Pengaruh Penambahan Tepung Garut (Maranta arrudinaceae) Terhadap Kualitas Fisik dan Organoleptik Nugget Kelinci. Jurnal Ilmu dan Teknologi Hasil Ternak, Vol. 8, No. 2, Hal. 922.

Karmas, E. 1982. Meat, Poultry and Sea Food Technology. Recent Development, Noyes Data Corporation Park Ridge. New jersey, USA.

Khomsan, Ali. 2006. Peranan Pangan dan Gizi untuk Kualitas Hidup. Jakarta : Grasindo.
Lawrie, R.A. 1995. Ilmu Daging. Jakarta : UI Press.

Marsono, Y. 2004. Serat Pangan dalam Perspektif Ilmu Gizi. Fakultas Teknologi Pertanian, Universitas Gadjah Mada.

Matz, S.A. 1962. Water in Food. Westport Connecticut : The AVI Publishing Company Inc.

Melliyana, D.V., Djalal Rosyidi, dan Eni Sri W. 2012. Pengaruh Penambahan Pati Biji Durian Terhadap Kualitas Fisik Nugget Ayam. http://fapet.ub.ac.id/wpcontent/uploads/2013/04/PengaruhPenambahan-Pati-Biji-DurianTerhadap-Kualitas-Fisik-NuggetAyam.pdf

Muchtadi, Deddy. 2001. Sayuran Sebagai Sumber Serat Pangan untuk Mencegah Timbulnya Penyakit Degeneratif. Jurnal Teknologi dan Industri Pangan, Vol. 12, No. 1.

Okada, M. 1990. Fish and Raw Material in Science of Processing Marine Food Product. Japan International Corporation. Hyoga International Centre.

Olivia, R., Lorensia Maria E.P., dan Fransiskus Sinung Pranata. 2013. Substitusi Tepung Kulit Udang Dogol (Metapenaeus monoceros Fab.) dalam pembuatan Nugget Jamur Tiram (Pleurotus ostreatus Jacq.). Fakultas Teknobiologi, Universitas Atmajaya Yogyakarta.

Permadi, S.N., S. Mulyani dan A. Hintono. 2012. Kadar Serat, Sifat Organoleptik dan Rendemen Nugget Ayam yang Disubstitusi dengan Jamur Tiram Putih (Perotus ostreatus). Jurnal Aplikasi Teknologi Pangan, Vol. 1, No.4.

Pinthuss, E.J., P. Weinberg, dan I.S Saguya. 1995. Oil Uptake in Deep Fat Frying as Affected by Porosing. Journal Food Science, Vol. 60, No. 1, Hal. 767-769.

Piscandika, T. Efrizal, dan Linda Waty Zen. 2006. Potensi dan Tingkat 
Pemanfaatan Ikan Tongkol (Euthynnus affinis dan Auxis thazard) yang Didaratkan pada Tempat Pendaratan Ikan Desa Malang Rapat Kecamatan Gunung Kijang Kabupaten Bintan Provinsi Kepulauan Riau,Bintan Provinsi Kepulauan Riau. Program Studi Manajemen Sumber Daya Perairan, Fakultas Ilmu Kelautan dan Perikanan, Universitas Kelautan Raja Ali Haji.

Portugal, T.R., Ma Rachel V.P., dan Mildred A. Udarbe. 2013. Proficiency Test on Total Dietary Fiber in Wheat Flour. International Journal of Chemical Engineering and Applications, Vol. 4, No. 2.

Prabowo, A.Y., Teti Estiasih, dan Indria Purwatiningrum. 2014. Umbi Gembili (Dioscorea esculenta L.) Sebagai Bahan Pangan Mengandung Senyawa Bioaktif : Kajian Pustaka. Jurnal Pangan dan Agroindustri, Vol. 2, No. 3, Hal. 129-135.

Prameswari, Rizki Dwi, dan Teti Estiasih. 2013. Pemanfaatan Tepung Gembili (Dioscorea esculenta L.) dalam Pembuatan Cookies. Jurnal Pangan dan Agroindustri, Vol. 1, No. 1, Hal. 115-128.

Purnomo, H. 1995. Studi Pengalengan Bakso. Malang : Brawijaya University Research Report.

Puspitasari, D. 2008. Kajian subtitusi Tapioka dengan Rumput Laut (Euchema cottoni) pada Pembuatan Bakso. Skripsi Fakultas Pertanian, Universitas Sebelas Maret. Surakarta.

Richana, N., dan Titi Chandra Sunarti. 2004 Karakterisasi Sifat Fisikokimia Tepung Umbi dan Tepung Pati dari Umbi Ganyong, Suweg, Ubi Kelapa dan Gembili. Jurnal Pascapanen, Vol. 1, No. 1, Hal. 29-37.

Roberfroid, M.B. 2005. Introducing Inulin Type Fructans. British Journal of Nutrition, Vol. 93.
Rospiati, Epi. 2006. Evaluasi Mutu dan Nilai Gizi Nugget Daging Merah Ikan Tuna (Thunnus sp.). Thesis, Danamandiri Online. http://www.Danamandiri.Or.Id/Deta il.Php?Id=531.

Rosyidi, D., Aris Sri Widati, dan Joko Prakoso. 2008. Pengaruh Penggunaan Rumput Laut Terhadap Kualitas Fisik dan Organoleptik Chicken Nuggets. Jurnal Ilmu dan Teknologi Hasil Ternak, Vol. 3, No. 1, Hal. 43-51.

Sanger, Grace. 2010. Oksidasi Lemak Ikan Tongkol (Auxis thazard) Asap yang Direndam dalam Larutan Ekstrak Daun Sirih. Pasific Journal, Vol. 2, No. 5, Hal. 870-873.

Soeparno. 1994. Ilmu dan Teknologi Daging. Yogyakarta : Gadjah Mada Press.

Statistik Kelautan dan Perikanan, Kementrian Kelautan dan Perikanan. 2012. Pusat Data, Statistik, dan Informasi Kelautan dan Perikanan. Kementrian Kelautan dan Perikanan. Sudarmaji, S., Horyono B.S. dan Suhardi. 1989. Analisa Bahan Makanan dan Pertanian. Yogyakarta : PAU Pangan dan Gizi UGM.

Sukarasa, D.R. 2004. Studi Aktivitas Asam lemak Omega 3 Ikan Laut pada Mencit Sebagai Model Hewan Percobaan. Buletin Teknologi Hasil Perikanan, Vol. VII, No. 1.

Surawan, F.E.D. 2007. Penggunaan Tepung Terigu, Tepung Beras, Tepung Tapioka, dan Tepung Maizena Terhadap Tekstur dan Sifat Sensoris Fish Nugget Ikan Tuna. Jurnal Sain Peternakan Indonesia, Vol. 2, No. 2.

Suryaningsih, A.W., Bambang Dwiloka, dan Bhakti Etza Setiani. 2015. Substitusi Susu Skim Dengan Tepung Kedelai Sebagai Bahan Pengikat Fungsional Nugget Daging Kerbau. Jurnal Aplikasi Teknologi Pangan, Vol. 4, No. 1.

Susanto, E., dan A.S. Fahmi. 2012. Senyawa Fungsional dari Ikan : Aplikasinya 
dalam Pangan. Jurnal Aplikasi Teknologi Pangan, Vol. 1, No. 4.

Suseno, T.I.P., Sutartjo Surjoseputro dan Ina Maria Fransisca. 2007. Pengaruh Jenis Bagian Daging Babi dan penambahan Tepung Terigu Terhadap Sifat Fisikokimiawi Pork Nugget. Jurnal Teknologi Pangan dan Gizi, Vol. 6, No. 2.

Suwamba, I Dewa Ketut. 2008. Proses Pemindangan dengan Mempergunakan Garam dengan Konsentrasi yang Berbeda. http://www.smpsaraswatidps.sch.id/index.php. Diakses pada 18 November 2014.

Suzuki, T. 1981. Fish and Krill Protein: Processing Technology. London: Applied Science Publishers Ltd.

Thiansilakul, Y., Soottawat Benajkul, dan Mark P. Richard. 2011. Isolation, Characterization, and Stabilityof Myoglobin from Eastern Little Tuna (Euthynnus affinis) Dark Muscle. Journal Food Chemistry, Vol. 124, Hal. 254-261.

Utami, R., Esti Widowati, dan Annisa Dyah A.R.D. 2013. Kajian Penggunaan
Tepung Gembili (Dioscorea esculenta) dalam Pembuatan Minuman Sinbiotik Terhadap Total Bakteri Probiotik, Karakter Mutu, dan Karakter Sensoris. Jurnal Teknosains Pangan, Vol. 2, No. 3.

Yuniar, Dina Printa. 2010. Karakteristik Beberapa Umbi Uwi (Dioscorea spp.) dan Kajian Potensi Kadar Inulinnya. Skripsi Program Studi Teknologi Pangan Fakultas Teknologi Industri, Universitas Pembangunan Nasional "Veteran" Jawa Timur.

Zhang, W., Shan Xiao, Himali Samaraweera, Eun Jo Lee, dan Dong U Ahn. 2010. Improving Functional Velue of Meat Products. Journal Meat Science, Vol. 86, Hal. 15-31.

Zubaidah, E. dan Wilda Akhdiana. 2013. Comparative Study of Inulin Extracts From Dahlia, Yam, and Gembili Tubers as Prebiotic. Food and Science Nutrition Sciences, Vol. 4, Hal. 8-12. 